\title{
Evaluation of Babolsar Sand Behaviour by Using Static Triaxial Tests and Comparison with Case History
}

\author{
Sina Salamatpoor*, Siavash Salamatpoor \\ Department of Civil Engineering, Najafabad Branch, Islamic Azad University, Najafabad, Iran \\ Email: ${ }^{\text {s s salamatpoor@sci.iaun.ac.ir, }}$ 녹a.salamatpoor@gmail.com
}

Received 29 June 2014; revised 3 August 2014; accepted 17 August 2014

Copyright (C) 2014 by authors and Scientific Research Publishing Inc.

This work is licensed under the Creative Commons Attribution International License (CC BY). http://creativecommons.org/licenses/by/4.0/

c) (i) Open Access

\begin{abstract}
An experimental study is carried out to investigate the static liquefaction of sand. For this purpose, Babolsar sand with its liquefiable parameters such as soil properties and high seismic level of underground water are investigated using static compression drained and un-drained tri-axial tests under isotropically and anisotropically conditions. Also, the data results of this sand are compared with those of the previous studies on soil case history. The study results indicate that Babolsar sand can experience the whole possible states of liquefaction soil, i.e. flow failure, limited and dilation behavior.
\end{abstract}

\section{Keywords}

Liquefaction Susceptibility, Triaxial Test, Isotropic, Anisotropic, Steady-State, Strength Ratio

\section{Introduction}

Liquefaction is one of the most important, complex and debatable phenomena in geotechnical earthquake engineering that its destruction affects due to lack of shear strength of soil have serious economic and environmental consequence on civil projects. Determination of liquefaction potential due to an earthquake is a complex problem in geotechnical engineering and entails a myriad of factors such as specifications of sand layers, high level of underground water and earthquake components.

The earthquakes in 1957 and 1971 in Bandpey and Babolkenar, respectively, as two cities located next to Babolsar led to the death of more than 1500 persons and complete destruction of more than 120 villages. Therefore, in short, it is necessity to investigate entire liquefaction condition in the southern bank of Caspian Sea.

"Corresponding author.

How to cite this paper: Sina Salamatpoor and Siavash Salamatpoor (2014) Evaluation of Babolsar Sand Behaviour by Using Static Triaxial Tests and Comparison with Case History. Open Journal of Civil Engineering, 4, 181-197. 
When the strain level is large enough, soil samples under sharing tend to be in a state of continuous deformation under constant shear and normal stress. It is believed that the behaviour of sand is collectively affected by such major factors as relative density, confining pressure and static shear stress. Static liquefaction is a phenomenon in which a large shift of the soil mass under a monotonic loading occurs due to a sudden increase of pore water pressure and thus confining effective stress. Also, Static liquefaction might be studied using triaxial apparatus to obtain a better understanding of the mechanism and parameters controlling the occurrence of flow type of failure. Castro (1969) [1] observed that cohesionless soils of different densities exhibit three basic phenomenological behaviors termed liquefaction, limited liquefaction and dilation under sufficient strain levels. These characteristics, along with the requirement of constant velocity, shear and confining stress has been defined as the steady-state [2]-[5]. The locus of the steady-state in $e-p^{\prime}-q$ space (where $e, p^{\prime}$, and $q$ are void ratio, mean effective stress, and deviatoric stress, respectively, at large strains) yields a state criterion for determining the susceptibility of sand to flow liquefaction or flow failure.

Jafarian et al. (2012) [6], observed that testing on anisotropically consolidated samples plays significant roles in stimulate liquefaction susceptibility of the soil within the sloping ground or beneath the structure which tolerate high shear stresses.

In this study, initial effective stress, shear stress, shear parameter $(\alpha)$ and relative density have been considered as state variables for evaluating the steady-state strength and liquefaction susceptibility of the poorly graded clean sand located at Babolsar region, Mazandaran province, Iran. Based on laboratory tests, for this sand, stress anisotropy can change the drained and undrained behavior of sand but the steady-state line is unique for either isotropically and anisotropically test conditions. Also, a comparison between the results of Babolsar sand and other results obtained by researchers on different types of sands indicates that there is a good correlation between behavior of Babolsar sand and that of different types of clean sands. Furthermore, investigations on such boundaries show that the results of Babolsar sand locate over Olson and Stark (2002) [7] band.

\section{Experimental Investigations}

\subsection{Description of Material Used}

The sand that is used for experiments is Babolsar natural sand, which underlies a densely populated, seismic region of the southern coast of Caspian Sea in Mazandaran, Iran. The reconstituted specimens of the sand were prepared using the bulk samples taken from the borrow pits on the beach. Figure 1 represents the location of sampling. The basic properties of this sand as determined in the laboratory are given in the Table 1 . According to the grain size distribution curve for the soil in Figure 2 the soil can be classified as per Unified Soil Classification System (USCS) as poorly graded sand with a group symbol SP. Figure 3 represents a microscopic view of the grains at round (a) 250 micrometer $(\mu \mathrm{m})$ and (b) 300 micrometer $(\mu \mathrm{m})$ shows the grains to be semi angular to semi rounded.

Table 2 and Table 3 show the mineralogical composition and morphological characteristics of Babolsar sand, respectively. Some of the terminologies used here are defined in the literature as follow.

Table 1. Comparison of $e_{\max }, e_{\min }, G_{s}, D_{50}, C_{u}$ for Babolsar sand.

\begin{tabular}{cccccc} 
Sand & $\mathrm{e}_{\max }$ & $\mathrm{e}_{\min }$ & $\mathrm{G}_{\mathrm{s}}$ & $\mathrm{D}_{50(\mathrm{~mm})}$ & $\mathrm{C}_{\mathrm{u}}$ \\
\hline Babolsar & 0.81 & 0.56 & 2.78 & 0.24 & 1.8 \\
\hline
\end{tabular}

Table 2. Mineralogical composition of Babolsar sand.

\begin{tabular}{cccccc}
\hline \multirow{2}{*}{ Sand } & \multicolumn{3}{c}{ Percentage mineral content } & & \\
\cline { 2 - 6 } & Quartz & Feldspar & Mica & Carbonate & Chlorite \\
\hline Babolsar & 46 & 27 & 11 & 16 & 0 \\
\hline
\end{tabular}

Table 3. Morphological characteristics of Babolsar sand.

\begin{tabular}{cccc}
\hline Sand & Average shape factor & Average sphericity & Average roundness \\
\hline Babolsar & 0.89 & 0.71 & 4.86 \\
\hline
\end{tabular}




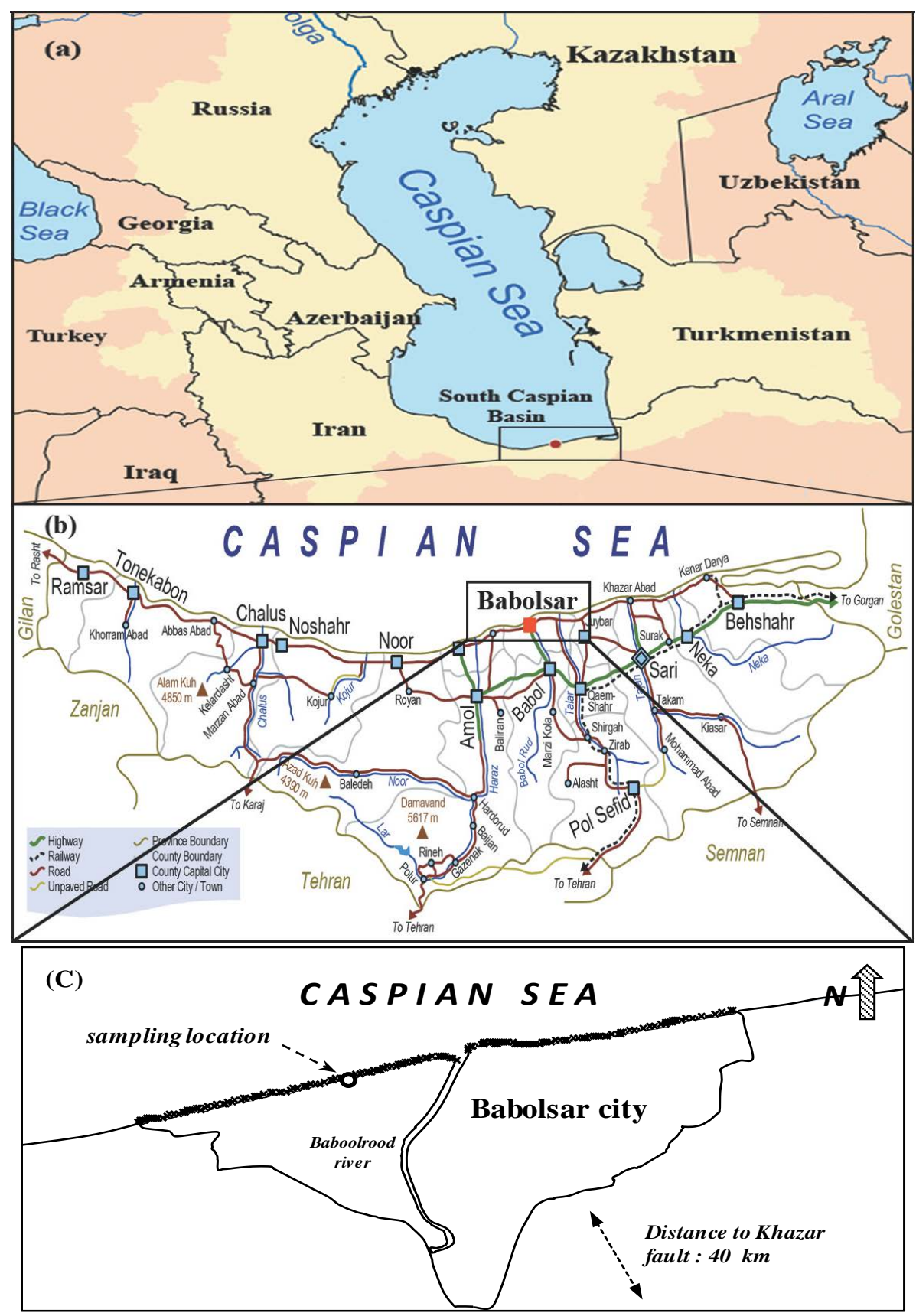

Figure 1. Plane of sampling (a) Caspian sea; (b) Southern Caspian Sea-Mazandaran; (c) Location of sampling station.

Wadell [8] defined sphericity as the ratio of the surface area of a sphere with the same volume as that of the particle and the actual surface area of the particle; roundness is a measure of the sharpness of the corners and edges of the grains and is defined as the ratio of the average radius of curvature of the corners to the radius of the largest inscribed circle. The shape factor (SF) is an index to define the aspects of a particle shape.

$$
S F=\frac{d_{S}}{\sqrt{\left(d_{L}-d_{I}\right)}}
$$

where $d_{L}, d_{I}$ and $d_{S}$ represent the longest, intermediate and the shortest particle dimensions respectively. Therefore, these mounts $d_{I} / d_{L}$ and $d_{S} / d_{I}$ for Babolsar clean sand are equal to 0.88 and 0.9 respectively. 


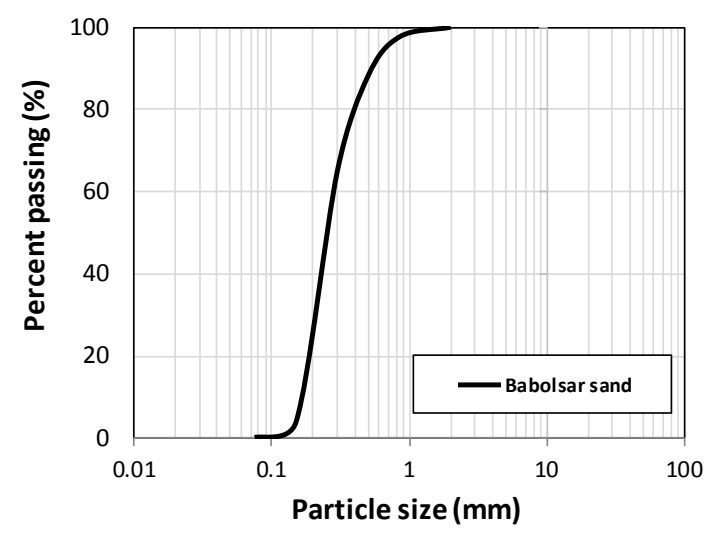

Figure 2. Particle size distribution curve of Babolsar sand.

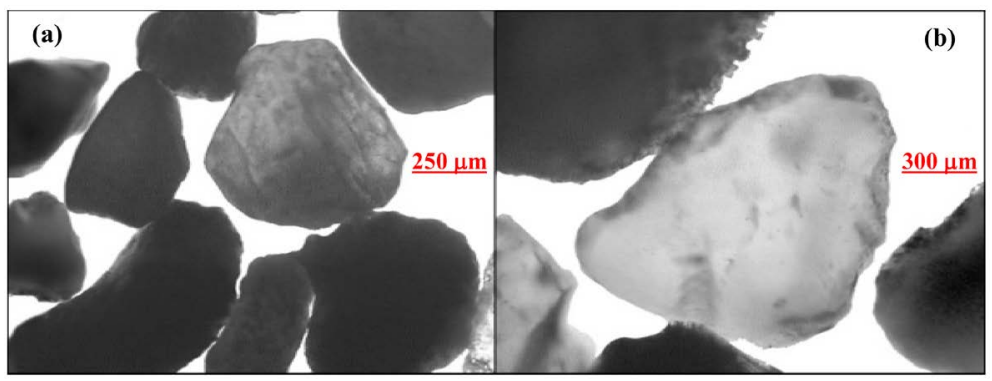

Figure 3. Microscopic view of Babolsar sand (a) $250 \mu \mathrm{m}$ and (b) $300 \mu \mathrm{m}$.

\subsection{Triaxial Apparatus}

The employed triaxial apparatus was a hand-made instrumented machine. Design and production of this apparatus involves four main parts, as described subsequently.

\subsubsection{Structure and Electro Mechanics}

The triaxial apparatus contains a steel frame and panel on which the dial gages and LVDTs together with many controller valves are installed. The main vertical hydraulic jack is installed beneath the desk and transfers axial compression or extension load with the velocity rate of 0.1 to $2.2 \mathrm{~mm} / \mathrm{min}$.

\subsubsection{Pneumatic}

Pneumatic force is supplied by a powerful air compressor in order to apply and control the following actions:

a) Applying the vacuum to make and protecting the sand samples in the mold and after remolding

b) Applying the confining pressure on the specimens

c) Applying back pressure

d) Applying the axial load with the pneumatic jack, installed for anisotropic loading

\subsubsection{Data Acquisition System}

The triaxial apparatus contains an electronic device which has 8 independent channels for analog to digital converting of pressure, displacement, and force measurements. Data acquisition is carried out using the software installed on computer for recording the required data. Figure 4 shows the mentioned hand-made triaxial apparatus with the data logger system.

\subsection{Sample Preparation}

Moist tamping has been adopted as a reasonable method for specimen preparation. The Oven-dried sands were carefully mixed with $5 \%$ of de-aired water and the wet samples were divided in five equal parts by weight. Each part was then carefully poured into the circular split-mold by a spoon and compacted into the mold to a prede- 


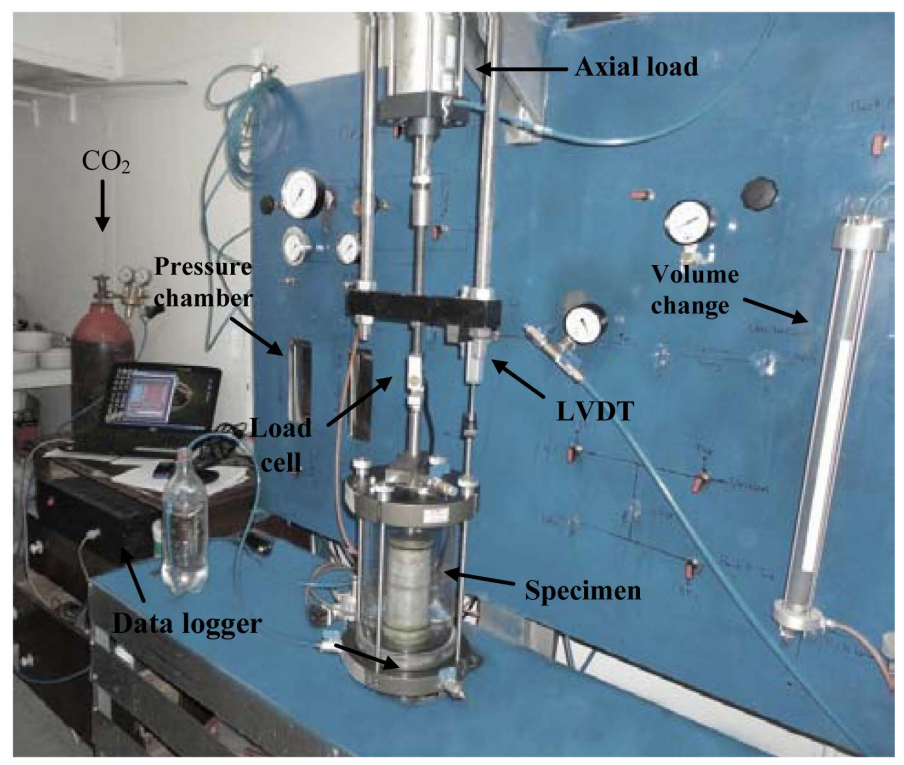

Figure 4. The static hand-made triaxial apparatus and data logger.

termined height and leveled with the caliper to achieve the desired density uniformly. The rubber membrane having $0.3 \mathrm{~mm}$ thickness was kept in position by applying suction between the mold and the membrane. The top of any compacted layer was then scarified to promote the required friction between the layers. The procedure was repeated for each of the five layers. Once, the sample was in the mold, the top cap was placed on the sample. A low level of vacuum was applied to the specimen and then sample height and diameter were measured. The target height and diameter of samples were tried to be $100 \mathrm{~mm}$ and $50 \mathrm{~mm}$, respectively. After detaching the mold, the cell was installed and the water supply was opened to fill out the cell with water. The confining pressure of about $10 \mathrm{kPa}$ was applying while the vacuum was removing simultaneously. The sample was blowing with carbon dioxide for easier saturation (e.g. to obtain a good degree of saturation, the technique of carbon dioxide worked out by Lad and Duncan [9], was used). The sample was firstly swept by carbon dioxide for $30 \mathrm{mi}-$ nutes. Then, de-aired water was flushed through the sample and a prescribed back pressure was applied to achieve the 95 percent or more saturation.

After consolidation and recording the squeezed water, strain-controlled drained or undrained loading with the rate of about $1 \mathrm{~mm} / \mathrm{min}$ was applied up to sample failure. For anisotropic tests, axial load was applied from the upper jack with a very low rate in drained condition prior to the undrained shearing. Also, Figure 5 shows prototyping process for Babolsar sand.

\subsection{Planning of Experiment}

Several drained and undrained tests under isotropic and anisotropic consolidations were conducted on Babolsar sand. The tests initial conditions are named as A to F series, as summarized in Table 4. A brief description of these tests is given as below:

A series: isotropically consolidated undrained (CIU-Test) triaxial tests, including 15 tests under initial mean effective stresses of 40 to $410 \mathrm{kPa}$ and initial relative densities of $5 \%$ to $55 \%$.

B series: isotropically consolidated drained (CID-Test) triaxial tests, including 10 tests under initial mean effective stress and relative densities the same as A series.

C series: anisotropically consolidated undrained (CAU-Test) triaxial tests, including 6 tests. For this condition, $\alpha$ was defined as the ratio of initial shear stress to effective confining stress (that initial shear stress is deviatoric stress divided by 2). Accordingly, $\alpha=0$ denotes isotropically consolidated specimens. For this series, $\alpha$ value is equal to 0.2 and initial mean effective stress is 40 and $300 \mathrm{kPa}$ while initial relative density varies from 5 to $55 \%$.

D series: anisotropically consolidated undrained (CAU-Test) triaxial tests, including 6 tests which are the same as $\mathrm{C}$ series except for $\alpha$ value of 0.4 . 
Table 4. Summary of static triaxial tests conducted during the current study.

\begin{tabular}{|c|c|c|c|c|c|c|c|c|}
\hline No. & Series & Type of consolidation & $\left(D_{r}\right)_{c}(\%)$ & Back pressure $(\mathrm{kPa})$ & B value (\%) & $\left(D_{\mathrm{r}}\right)_{\mathrm{cr}}(\%)$ & $\mathrm{P}_{0}^{\prime}(\mathrm{kPa})$ & $\alpha\left(\tau / \sigma_{3 c}^{\prime}\right)$ \\
\hline 1 & A & CIU & 8.48 & 48 & $>97$ & & 40 & 0 \\
\hline 2 & A & CIU & 11.77 & 49 & $>98$ & & 110 & 0 \\
\hline 3 & A & CIU & 15.07 & 58 & $>95$ & & 210 & 0 \\
\hline 4 & A & $\mathrm{CIU}$ & 18.37 & 51 & $>97$ & & 300 & 0 \\
\hline 5 & A & CIU & 20.2 & 54 & 100 & & 410 & 0 \\
\hline 6 & A & $\mathrm{CIU}$ & 33 & 42 & $>95$ & & 40 & 0 \\
\hline 7 & A & $\mathrm{CIU}$ & 36.54 & 50 & $>95$ & & 110 & 0 \\
\hline 8 & A & CIU & 41.49 & 51 & $>98$ & & 210 & 0 \\
\hline 9 & A & $\mathrm{CIU}$ & 42 & 53 & $>97$ & & 300 & 0 \\
\hline 10 & A & $\mathrm{CIU}$ & 42.55 & 53 & $>96$ & & 410 & 0 \\
\hline 11 & A & CIU & 56.87 & 81 & $>98$ & & 40 & 0 \\
\hline 12 & A & CIU & 59.77 & 52 & 100 & & 110 & 0 \\
\hline 13 & A & CIU & 61.3 & 53 & $>96$ & & 210 & 0 \\
\hline 14 & A & CIU & 62.73 & 52 & $>98$ & & 300 & 0 \\
\hline 15 & A & CIU & 65.05 & 53 & $>96$ & & 410 & 0 \\
\hline 16 & B & CID & 7.93 & 52 & $>96$ & 3.33 & 40 & 0 \\
\hline 17 & B & CID & 10.52 & 47 & $>95$ & 5.6 & 110 & 0 \\
\hline 18 & B & CID & 13.61 & 45 & $>98$ & 9.74 & 210 & 0 \\
\hline 19 & B & CID & 18.37 & 44 & 100 & 13.95 & 300 & 0 \\
\hline 20 & B & CID & 22.47 & 45 & $>97$ & 36.51 & 410 & 0 \\
\hline 21 & B & CID & 57.39 & 52 & $>95$ & 29.11 & 40 & 0 \\
\hline 22 & B & CID & 58.44 & 43 & $>95$ & 31.63 & 110 & 0 \\
\hline 23 & B & CID & 61.3 & 51 & $>98$ & 37.78 & 210 & 0 \\
\hline 24 & B & CID & 64.44 & 44 & $>95$ & 49.76 & 300 & 0 \\
\hline 25 & B & CID & 64.95 & 47 & 100 & 45.15 & 410 & 0 \\
\hline 26 & C & CAU & 9.39 & 41 & $>97$ & & 45.34 & 0.2 \\
\hline 27 & C & CAU & 19.83 & 53 & 100 & & 340 & 0.2 \\
\hline 28 & C & CAU & 34.06 & 51 & $>98$ & & 45.34 & 0.2 \\
\hline 29 & C & CAU & 40.25 & 43 & $>95$ & & 340 & 0.2 \\
\hline 30 & C & CAU & 57.21 & 51 & $>96$ & & 45.34 & 0.2 \\
\hline 31 & C & CAU & 64.03 & 52 & 100 & & 340 & 0.2 \\
\hline 32 & D & CAU & 9.03 & 52 & $>97$ & & 50.66 & 0.4 \\
\hline 33 & D & CAU & 18.91 & 54 & $>96$ & & 380 & 0.4 \\
\hline 34 & D & CAU & 33.36 & 51 & $>96$ & & 50.66 & 0.4 \\
\hline 35 & D & CAU & 42.2 & 43 & $>98$ & & 380 & 0.4 \\
\hline 36 & D & CAU & 57.04 & 44 & $>95$ & & 50.66 & 0.4 \\
\hline 37 & D & CAU & 68.12 & 48 & $>97$ & & 380 & 0.4 \\
\hline 38 & $\mathrm{E}$ & CAD & 7.45 & 44 & $>97$ & 8.95 & 45.34 & 0.2 \\
\hline 39 & $\mathrm{E}$ & CAD & 17.78 & 46 & $>96$ & 11.59 & 340 & 0.2 \\
\hline 40 & $\mathrm{E}$ & CAD & 57.21 & 47 & 100 & 29.91 & 45.34 & 0.2 \\
\hline 41 & $\mathrm{E}$ & CAD & 63.48 & 48 & $>97$ & 41.31 & 340 & 0.2 \\
\hline 42 & $\mathrm{~F}$ & CAD & 7.67 & 74 & $>96$ & 4.46 & 50.66 & 0.4 \\
\hline 43 & F & CAD & 17.63 & 75 & $>96$ & 15.4 & 380 & 0.4 \\
\hline 44 & F & CAD & 57.32 & 40 & $>98$ & 35.11 & 50.66 & 0.4 \\
\hline 45 & F & CAD & 63.79 & 77 & $>98$ & 42.14 & 380 & 0.4 \\
\hline
\end{tabular}




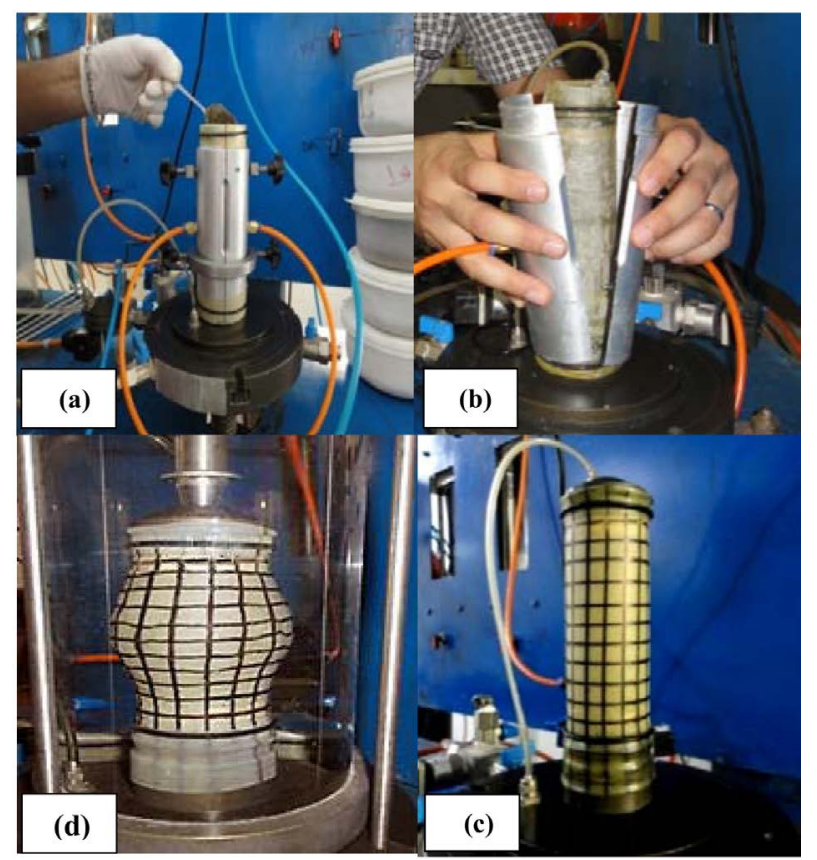

Figure 5. The process of sample preparation (a) pouring sand into mold; (b) open the mold and applying suction to sample maintenance; (c) prepare samples for testing and (d) at the end of the test specimens deformed.

E series: anisotropically consolidated drained (CAD-Test) triaxial tests, including 4 tests under initial mean effective stress of 40 and $300 \mathrm{kPa}$, initial relative density of 5 and $55 \%$, and $\alpha=0.2$.

F series: anisotropically consolidated drained (CAD-Test) triaxial test, including 4 tests which are the same as E series except for $\alpha$ value of 0.4 .

\section{Results and discussions}

\subsection{Effect of Load Anisotropically on Stress, Strain and Excess Pore Water Pressure}

Initial shear load parameter $(\alpha)$, which is created anisotropically consolidated specimens, can vary some soil parameters. For comprehensive this method, Figure 6 shows behaviour of two loose (A1 and D32) and two dense (A14 and C31) samples in $q-\varepsilon_{\mathrm{a}}, \Delta \mathrm{u}-\varepsilon_{\mathrm{a}}$ and $q-p^{\prime}$ planes. The liquefied sample A1 shown in Figures 6(a)-(c) exhibits a contractive behaviour throughout the shearing. When undrained shearing starts, the specimens with a contractive behaviour generate positive excess pore water pressure, and shear resistance reaches a peak value at a relatively small strain. In addition, specimens would then collapse (Figure 6(c)). After peak point, the excess pore water pressure increases dramatically and the stress path reaches the steady-state line with considerable strain softening. In these cases, the specimens exhibit flow liquefaction behaviour in which the static shear stress required for equilibrium (peak point) are greater than the available shear strength in steady-state condition. The stress path of the liquefied specimens A1 starts from the mean effective stress of $40 \mathrm{kPa}$ while its post-consolidation relative density was $8.48 \%$. When the initial axial shear load was applied in an undrained condition to obtain anisotropically consolidation, the sample showed a different behavior. For example, specimens D32 which was anisotropically consolidated under $\alpha=0.4$ condition (initial shear load $=6.28 \mathrm{~kg}$ ) showed a dilative behavior while its relative density was approximately equal to that of A1 specimen. Accordingly, the shear resistance of D32 increased significantly (96.75\%) while its initial deviatoric stress is not considerably larger than A1 (zero initial deviatoric stress for A1 and $32 \mathrm{kPa}$ for D32). Hence, although the initial mean effective stress of D32 ( $\left.\mathrm{p}_{0}^{\prime}=50.66 \mathrm{kPa}\right)$ was larger $\left(\mathrm{p}_{0}^{\prime}=40 \mathrm{kPa}\right.$ for A1 test), soil behavior was switched from contractive to dilative due to the anisotropically consolidation. The curves of deviatoric stress and excess pore water pressure versus axial load as well as effective stress path are shown through Figures 6(a)-(c). Similar findings has been obtained for the dense specimens (A14 and C31), but the effect of initial shear is more profound for the 


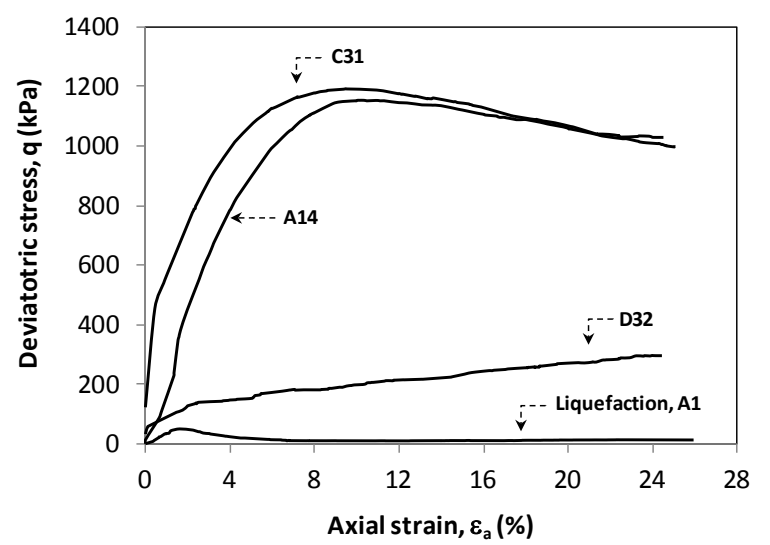

(a)

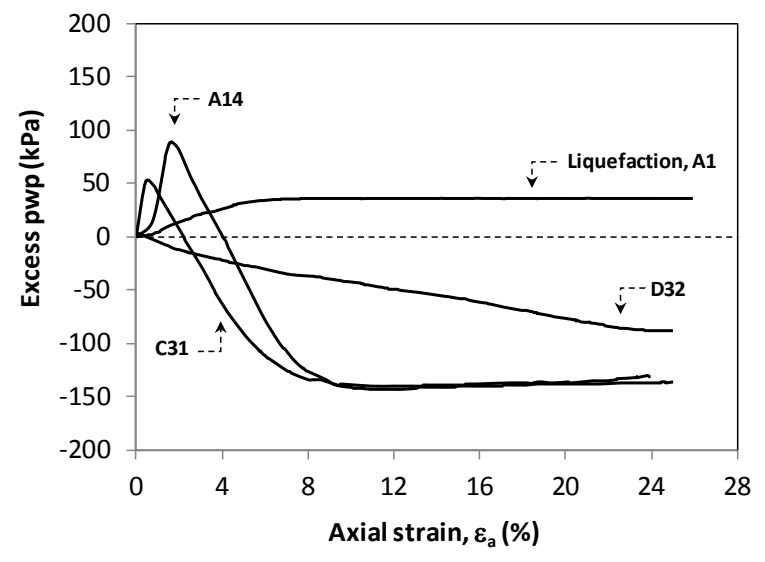

(b)

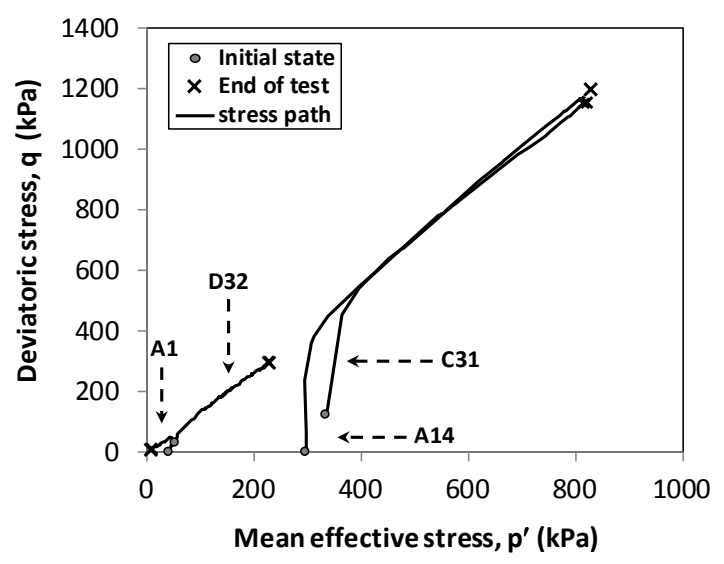

(c)

Figure 6. Test results of A1, A14, D32, and C31samples (a) Stress-strain curves; (b) Excess pore water pressure versus axial strain; and (c) Effective stress paths.

loose ones. Details of A1, A14, C31 and D32 tests are presented in Table 4. The dense specimens A14 show a dilative behavior under mean effective stress $300 \mathrm{kPa}$ and relative density after consolidation $62.73 \%$. The sample at first created positive pore water pressure and then by continuing the axial strain, it converted the pore water pressure to negative (Figure 6(b)). When the shear parameter $0.2(\alpha=0.2)$ was applied on the sample C31, the mean effective stress varied from $300 \mathrm{kPa}$ to $340 \mathrm{kPa}$ under the isotropically and anisotropically conditions, respectively. This process influences relative density and stress path, thus by applying the shear parameter 0.2 on A14 sample which created C31 condition, the relative density alter from $62.73 \%$ to $64.03 \%$ on A14 and C31 respectively, which is presented that existence of shear parameter obtained dilative behaviour for samples (Figures 6(a)-(c)). Therefore, it is observed that the initial shear load considerably affects the stress paths and sand behavior. In fact, the experimental results of the current study reveals that any increase in the initial shear stress gives rise to increase in the deviatoric and mean effective stresses at failure.

\subsection{Steady-State Line (SSL)}

For the soils, when the strain level is large enough, soil samples under shearing tend to be in a state of continuous deformation under constant shear $(q)$ and normal stresses $\left(p^{\prime}\right)$. There exists a correlation between the ultimate values of void ratio and mean effective principal stress, which is referred to as the ultimate steady-state line (SSL). Soil behaviour can be obtained by expressing the state of effective confining stress and defining the location of this point relative to the steady-state line. The SSL is defined as the locus of all points within the void ratio-effective stress $\left(e-p^{\prime}\right)$ plane at which a soil mass deforms under condition of constant stress and void ratio. The steady-state concept and SSL have been well described by others [1]-[4] [10]. Poulos et al. (1985) [11], made systematic measurements of steady strength by using stress-controlled CU triaxial tests. Also, Poulos et al. 
(1985) [11] and Fear and Robertson (1995) [12] studied the effect of grain size characteristics and grain size compositions of soils.

The results of all tests for Babolsar sand in $q-p^{\prime}$ and $e-p^{\prime}$ planes are shown in Figures 7(a)-(c), respectively. Figure 7(a) illustrates the stress paths for isotropically consolidated undrained (Series A) and drained ones (Series B). The stress paths due to drained tests have 1 to 3 slopes in $q-p^{\prime}$ space until reach to steady-state line. The steady-state line for isotropic condition has 54.26 angle $(M=1.39)$. Figure $7(b)$ shows that stress paths for anisotropically consolidated under drained and undrained conditions (i.e. series C, D, E and F) according to Table 4. For these series, shear parameter $(\alpha)$ time test increases in constant initial mean stress and leads to an increase in the mean confine effective stress and deviatoric stress in specimens. The $\mathrm{M}$ parameter for anisotropic conditions is 1.4 (the SSL line in this case has 54.46 angle). Results of all tests for Babolsar sand in $e-p$ ' plan are shown in Figure 7(c). As seen, results of the tests with different initial stress-density conditions such as isotropic or anisotropic consolidation, drained or undrained, and various relative densities fall along a unique steady-state line. By plotting the experimental data in $e-p^{\prime}$ plane (Figure 7(c)), nonlinear equation for the steadystate line is achieved by regression $\left(\mathrm{e}=0.7723-0.0454 \log p^{\prime}\right)$. Data scattering is observed in Figure 7(c) especially for larger $p^{\prime}$ values wherein the majority of the data are located. Therefore, experimental results of the current study reveals that isotropically and anisotropically compressed sample approaches toward a unique and identical steady-state line.

\subsection{Effect of Relative Density}

Behavior of sand is controlled by its density and confining pressure. Relative density is a commonly used index to describe the state of sand. (However, it is well known that relative density cannot fully determine the mecha-

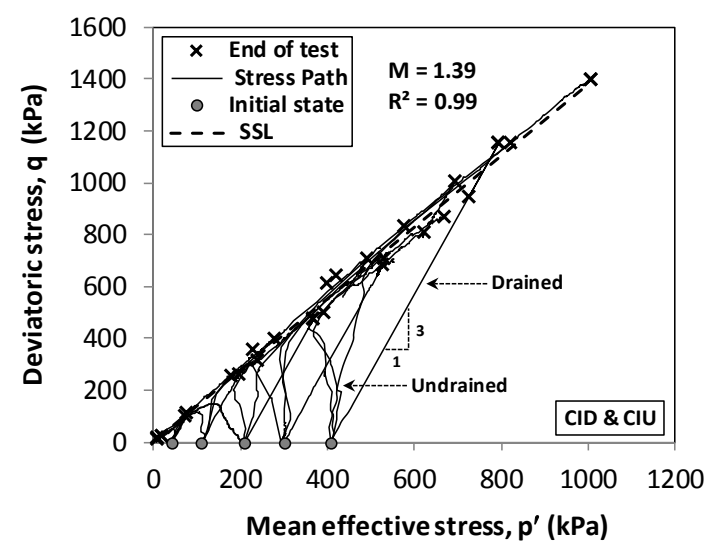

(a)

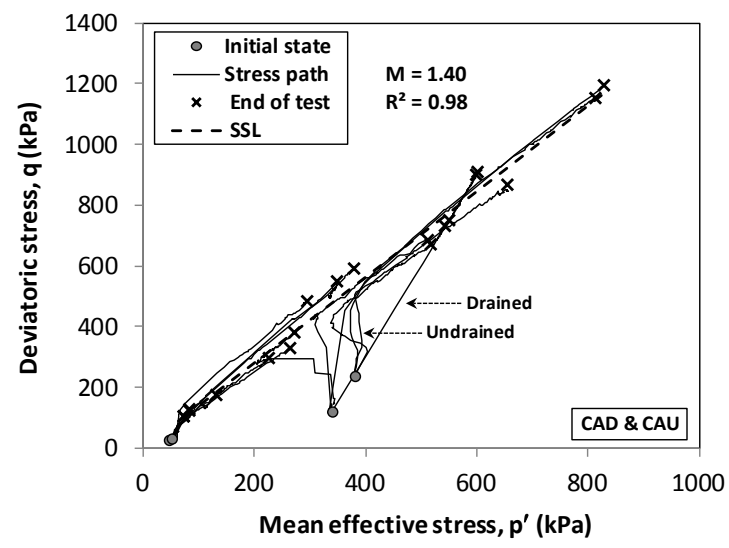

(b)

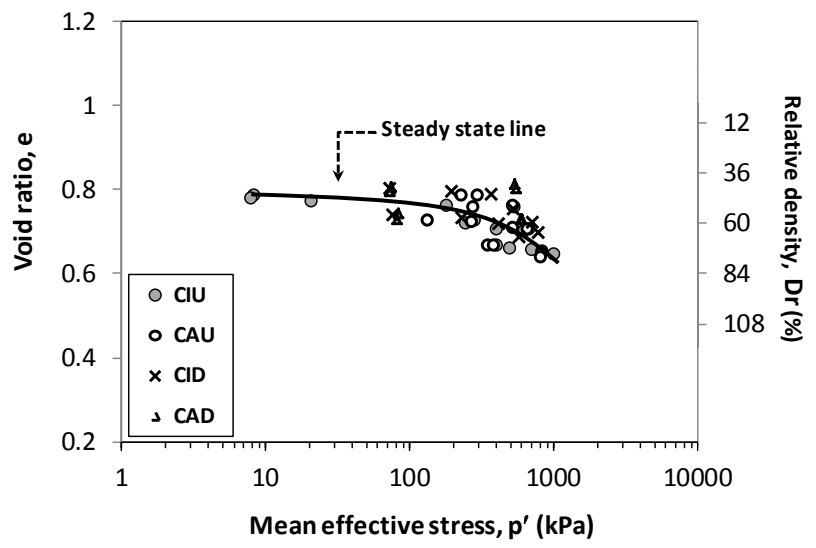

(c)

Figure 7. (a) Effective stress paths for isotropic conditions (series A and B) (b) effective stress paths for anisotropic conditions (series C, D, E and F) (c) The steady-state line for all specimens in (a) $e-p^{\prime}$ plane. 
nical behavior of sand). Figure 8(a) shows effective stress paths behavior of specimens at three different relative densities that were initially subjected to the same consolidated pressure of $210 \mathrm{kPa}$. For loose specimen A1 with relative density $15.07 \%$, the stress path shows liquefaction behavior while, for sample A8 by relative density $41.49 \%$ (medium dense) the specimen shows dilative treat. Also, by increasing relative density values, the deviatoric stress and mean effective stress will be increased at failure moment. For example, the dense specimens, A13 with relative density $61.3 \%$ has completely dilative behavior while deviatoric and mean effective stresses at failure in comparison by the sample A8 are 1.57 (784/498, kPa) and $1.4(541 / 385, \mathrm{kPa})$ times respectively. Therefore, in constant mean effective stress, by increasing relative density the behavior of this sand shifted from a liquefiable (loose) into a dilative (dense) state.

For isotropically and anisotropically specimens, variation of the ratio pore pressure at failure to the initial effective confining pressure, $\mathrm{r}_{\mathrm{u}}\left(\mathrm{u}_{\text {excess }} / \sigma_{3 c}\right)$ were plotted versus friction angle at failure $\left(\phi^{\prime}\right)$, as shown Figure 8(b). $r_{u}$ might be considered as a criterion for liquefaction susceptibility. Besides, the term $r_{u}$ for liquefaction states ranges between 0 to 1 and whatever term ru next to 1 , the liquefaction potential will be increased. Accordingly, the data for entire undrained tests under the isotropically and anisotropically condition can be located between two boundaries. The samples with positive $r_{u}$ values denotes flow failure or probably limited flow failure types of soil behavior which only occurred for the isotropic tests. (See, the boundaries are close to each other). Increasing the relative density, confined pressure and shear parameter can shift the sand behavior from contractive (strain softening) to dilative (strain hardening) one. This state shows the dilative behavior of the specimens which are presented in these conditions and located beneath the zero line of the $r_{u}$. Also, in Figure 8(b) the shadowed anisotropic region is related to the specimens which are susceptible to shear parameter. Due to the applied shear parameter and dilative behavior of these specimens, $r_{u}$ takes negative values (see the shadowed region). However, one anisotropically compressed sample has demonstrated limited flow failure with a very low positive $r_{u}$ value. This region of Figure 8(b) belongs to the anisotropically tests and this implies very lower tendency of anisotropic samples to flow failure.

\subsection{Collapse Line}

Loose sand specimens under high initial confining pressure are expected to exhibit contractive behaviour, thereby reaching the peak strength followed by significant strain softening or flow failure until the steady-state. As discussed by Olson and stark (2003) [13] and Hanzawa et al. (1979) [14] indicated that peak shear strength measured during shear tests produced an approximately linear peak shear strength envelope in stress path space. Sladen et al. (1983) [15] defined a collapse surface in three-dimensional void ratio-shear stress-effective normal stress space to represent condition that would lead to the triggering of flow liquefaction, or strain softening behavior. The collapse surface represents the locus of peak (or yield) shear stresses that a given soil can reach varying combinations of void ratio and mean effective stress. A number of other investigations (e.g., Vaid and

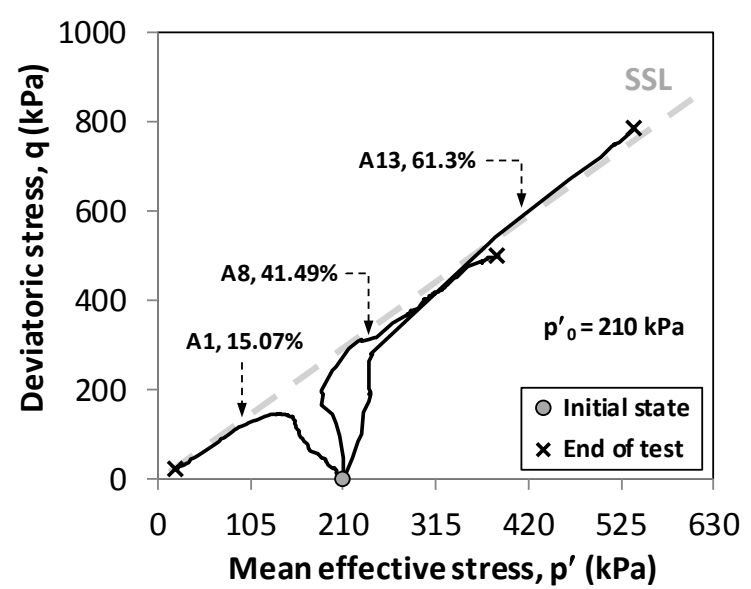

(a)

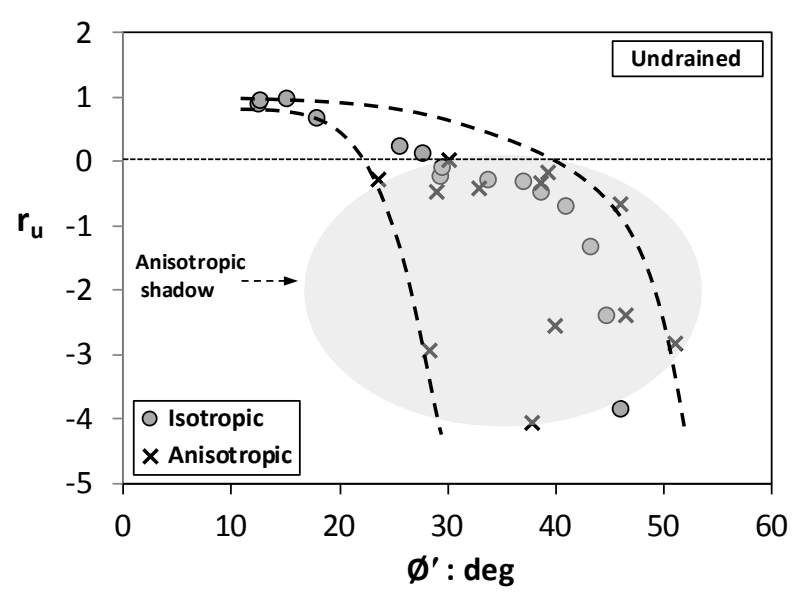

(b)

Figure 8. (a) effect of relative density on various reconstitutes samples with same initial mean effective stress; (b) Variation of pore pressure ratio at failure versus friction angle at failure for isotropic and anisotropic tests. 
Chern (1983) [16], Kramer and Seed (1988) [17], Vasquez-Herrera and Dobry (1989) [18], Lade (1992) [19], (1993) [20], Ishihara (1993) [21], Konrad (1993) [22], Sasitharan et al. (1993) [23], (1994) [24] and among others) identified similar yield conditions and proposed various names for these conditions.

The collapse line is considered as a limit state boundary between the stable and the unstable states of soil undrained behaviour. For the isotropically consolidated specimens of Babolsar sand, undrained shearing has resulted in only three flow liquefactions for the loose specimens A1, A2 and A3. Figure 9(a) shows that the collapse line and the steady-state line are inclined at the angles of $47.17^{\circ}$ and $54.15^{\circ}$ degrees above the horizontal, respectively. Of course, the slope of the $M_{L}$ can be related to Mohr-Coulomb effective friction angle at yield, $\phi_{y}$ as follow:

$$
\operatorname{Sin} \phi_{y}=\frac{3 M_{L}}{6+M_{L}}
$$

The slope of collapse line in triaxial compression Figure 9(b) shows the boundary which is accumulated by Olson and Stark (2003) [13] from thirteen different clean sands in the world. The properties of these sands are shown in Table 5. For this bound the slope of the collapse surface in triaxial compression ranges from approx-

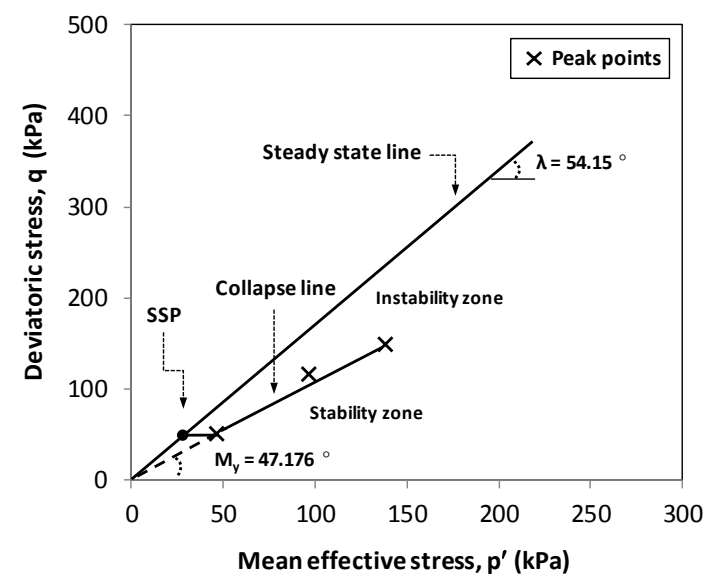

(a)

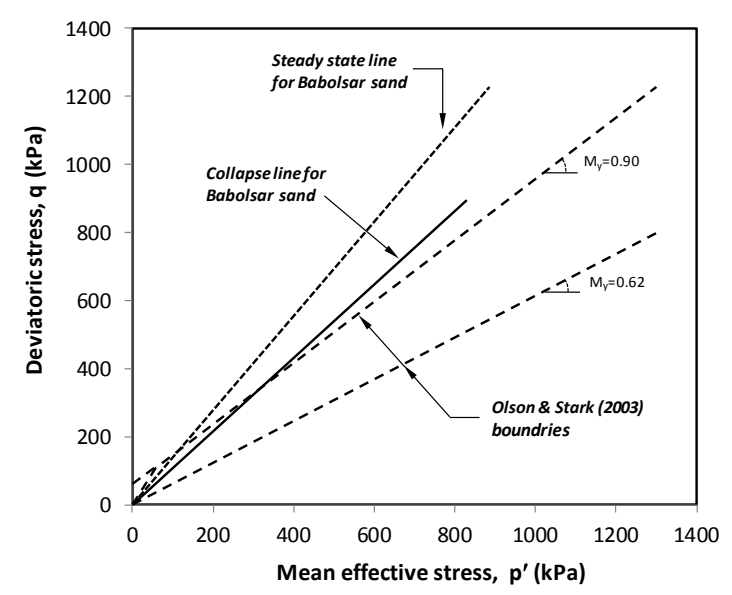

(b)

Figure 9. (a) Definition of collapse line; (b) comparison between collapse lines ranges and data Babolsar sand.

Table 5. Laboratory data for clean sands (after Olson and Stark (2003) [13]).

\begin{tabular}{|c|c|c|c|c|c|c|c|}
\hline Sand No. & Sand name & $\mathrm{D}_{50}(\mathrm{~mm})$ & $\mathrm{FC}(\%)$ & $\mathrm{e}_{\max }$ & $\mathrm{e}_{\min }$ & Slope, $\lambda$ & Reference \\
\hline 1 & Dune sand & 0.21 & 3 & $0.91(\mathrm{~A})$ & $0.54(\mathrm{~A})$ & 0.1625 & Konard [25] \\
\hline 2 & Well-rounded silica sand (WA) & 0.175 & 1 & $1.06(\mathrm{~A})$ & $0.67(\mathrm{~A})$ & 0.02932 & Konard [25] \\
\hline 3 & Hostun RF sand & 0.38 & 0 & 1 & 0.656 & - & Canou et al. [26] \\
\hline 4 & Nerlerk 0\% - 2\% & $0.23-0.28$ & $0-2$ & $0.94(\mathrm{C})$ & $0.62(\mathrm{C})$ & 0.04 & Sladen et al. [15] \\
\hline 5 & Monterey \#9 Sand & 0.35 & 0 & $0.86(\mathrm{E})$ & $0.53(\mathrm{I})$ & - & $\begin{array}{c}\text { Riemer et al. [27], } \\
\text { Riemer and Seed [28] [29] }\end{array}$ \\
\hline 6 & Sydney sand & 0.3 & - & 0.855 & 0.565 & - & Chu $[30]$ \\
\hline 7 & Hostun RF sand & 0.32 & 0 & 1 & 0.655 & 0.0735 & Konard [22] \\
\hline 8 & Massey Tunnel sand & 0.25 & 3 & $1.102(\mathrm{~F})$ & $0.712(\mathrm{~F})$ & - & Konard and Pouliot [31] \\
\hline 9 & Quebec sand & 0.5 & 0 & $0.79(\mathrm{~B})$ & $0.54(\mathrm{~F})$ & 0.021 & Konard [32] \\
\hline 10 & Ottawa sand & 0.34 & 0 & $0.82(\mathrm{~A})$ & $0.5(\mathrm{~A})$ & 0.0387 & Sasitharan et al. [23], [24] \\
\hline 11 & Sand B & 0.16 & 0 & $0.84(\mathrm{G})$ & $0.5(\mathrm{G})$ & 0.05 & Castro and Poulos [3]; Castro [1] \\
\hline 12 & Sand C & 0.27 & 1 & $0.99(\mathrm{G})$ & $0.66(\mathrm{G})$ & 0.050 & Castro and Poulos [3]; Castro [1] \\
\hline 13 & Sand A & 0.2 & 2 & $1.88(\mathrm{G})$ & $1.23(\mathrm{G})$ & 0.75 & Castro [1] \\
\hline
\end{tabular}

Note: Maximum $\left(\mathrm{e}_{\max }\right)$ and minimum $\left(\mathrm{e}_{\min }\right)$ void ratios were determined using the following methods as indicated in parentheses: (A): ASTM D2049-69 (as reported by investigators); (B): Kolbuszewski (1948) [33]; (C): unspecified ASTM procedure; (E): dry pluviation; (F): ASTM D4254 (as reported by investigators); (G); nonstandard procedure; -: not available. 
imately $0.62\left(31.8^{\circ}\right)$ to $0.90\left(41.98^{\circ}\right)$. As it is shown in Figure 9(b), a comparison between the boundary presented (collapse lines) by Olson and Stark (2003) [13] and also collapse lines for Babolsar sand with 47.17 angle shows that this line is located over the boundary. Therefore, it could be said that Babolsar clean sand has a higher liquefaction potential than these 13 different types of sand in the world, which have been compared by Olson and Stark (2003) [13].

\subsection{State Parameter $(\psi)$}

Soil behaviour can be described by positioning of the current stress-density state of soil relative to the steadystate line. Therefore, one can say that sand behaviour not only is dependent upon its relative density but also a description of stress state has to be defined. Been and Jefferies (1985) [5] demonstrated that the current state is expressed in terms of both initial void ratio $e_{0}$ and effective mean stress, $p_{0}^{\prime}$. Hence, different combinations of $\mathrm{e}_{0}$ and $p_{0}^{\prime}$ can potentially obtain the whole possible phenomenological types of soil behaviour. State parameter $(\psi)$ has been defined as the difference between the current void ratio and the void ratio at the same mean effective stress on the SSL in $e-p$ ' plane:

$$
\psi=e-e_{\mathrm{ss}}
$$

where $e$ is the current void ratio of the soil, $e_{\mathrm{ss}}$ is the void ratio of the soil on steady-state line at the same effective stress.

In undrained shearing, a positive $\psi$ value is typically associated with flow failure, whereas a negative $\psi$ value is associated with non-flow behaviour. Therefore, the state parameter can be used for describing the behaviour of granular materials over a wide range of initial stress-density conditions. In fact, state parameter properly combines these parameters which are physically relevant to describe the behaviour of granular materials.

The peak strengths of sands are known to be dependent upon the initial density of packing and the effective stress level. The combined influence of stress level and density on strength were studied and reported by Bolton (1986) [41] and Been and Jefferies (1985) [5]. Bolton (1986) [34] suggested that the difference between the peak and steady-state angles of friction can be estimated from Equation (4):

$$
\phi^{\prime}-\phi_{s s}^{\prime}=3\left[I_{D}\left(10-\ln p_{f}^{\prime}\right)-1\right]
$$

where $\phi^{\prime}$ and $\phi_{s s}^{\prime}$ are peak and steady-state angles of friction, respectively, measured in degrees $\left(0<\phi^{\prime}-\phi_{s s}^{\prime}<\right.$ $12^{\circ}$ ), ID is initial relative density and $p_{f}^{\prime}$ is the mean effective stress at failure.

For the isotropic consolidated drained (CID) and undrained (CIU) tests (A and B series), the values of $\phi$ ' were calculated as the friction angle at failure and the values of $\phi_{s s}^{\prime}$ were estimated when stress path reached the steady-state line. As shown in Figure 10(a), the values of $\phi^{\prime}-\phi_{s s}^{\prime}$ were found to be between 0 and 12 degrees (0 $<\phi^{\prime}-\phi_{s s}^{\prime}<12^{\circ}$ ) for A and B series. The figure also shows the upper and lower bounds reported by Been and

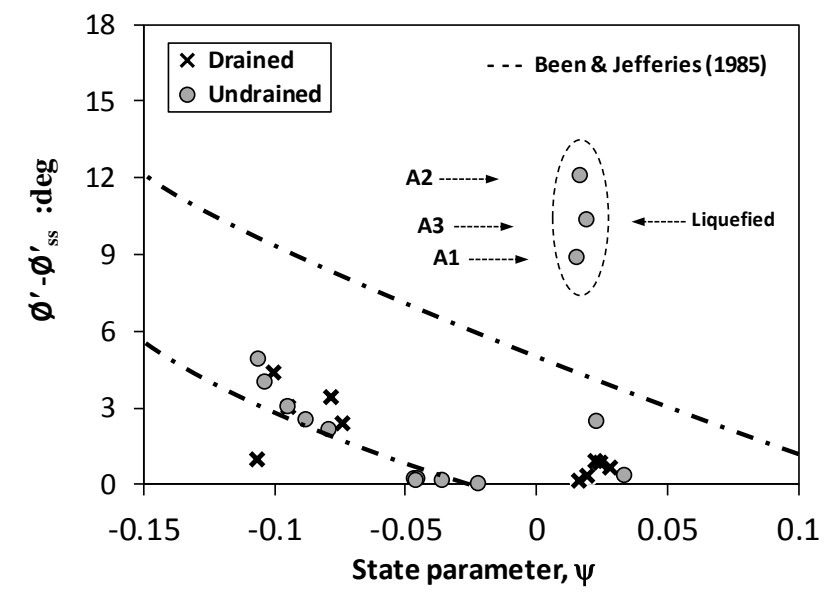

(a)

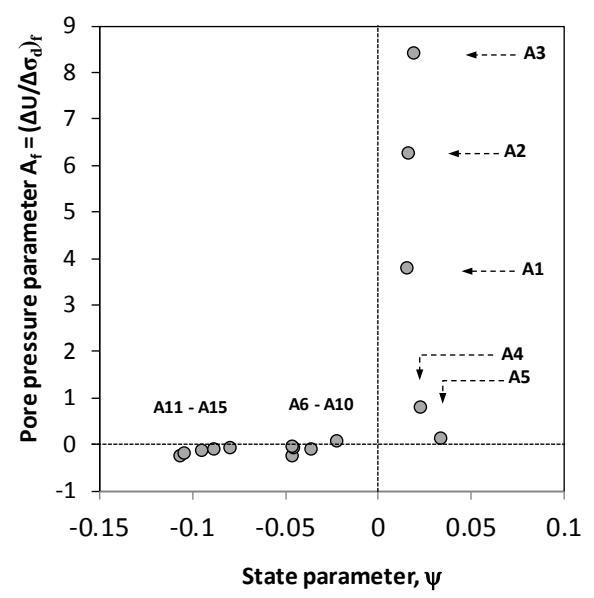

(b)

Figure 10. (a) Difference between peak and steady-state friction angles versus state parameter for isotropic drained and undrained conditions; (b) pore pressure parameter versus state parameter for isotropic undrained conditions. 
Jefferies (1985) [5] for six different clean and silty sands. Although majority of the tests data specify the $\phi^{\prime}-\phi_{s s}^{\prime}$ values less than 5 degrees and fall within the Been and Jefferies (1985) [5]'s range, it is seen that three liquefied samples have obtained out of range results. As indicated by Been and Jefferies (1985) [5], this is due to the inaccuracies associated with the determination of $\phi^{\prime}$ from the results of the liquefied samples. Also, to better realize effectiveness of the state parameter, the curvature of Skempton pore pressure parameter versus state parameter for isotropically consolidated undrained conditions (A series) are plotted (Figure 10(b)). As it is shown in the Figure 10(b), for three liquefiable tests A1 to A3, by increasing the mean effective stress, pore water pressure in collapse moment and accordingly the Skempton parameter $\left(\mathrm{A}_{\mathrm{f}}\right)$ will be increased. It must be noted that this state is related to positive state parameter. For A6 to A15 tests shown in (10b), increase in the relative density (also average effective pressure) results in a change of behavior from a contractive state into a dilative state (pore water pressure in collapse time) which these state is related to negative values in Skempton parameter and state parameter.

Therefore, it can be said that there is a remarkably good correlation between Skempton parameter and state parameter in specifying liquefiable or non-liquefiable state of the specimen.

\subsection{Liquefied and Yield Strengths}

In the current study, among the isotropically consolidated undrained (CIU) tests from Series A, three loose samples A1 to A3 which are exhibit contractive behaviour throughout the shearing. When undrained shearing begins, the specimens with contractive behaviour generate positive excess pore water pressure and shear resistance reaches a peak value that occurs at a relatively small strain and the specimens would then collapse.

After peak point, excess pore water pressure increases dramatically and the stress path reaches the steadystate line with considerable strain softening. In these cases, the specimens have exhibited flow liquefaction behaviour in which the static shear stress required for equilibrium (peak point) are greater than the available shear strength in steady-state condition.

Seed (1987) [35] developed a correlation between SPT resistance and the apparent shear strength back-calculated from observed flow failures and lateral spreads. Also Seed (1987) [35] back analyzed some 12 case studies of flow sliding (or large deformation) and developed a correlation of residual undrained strength to the equivalent clean sand SPT blow count, (N1) $)_{60-\mathrm{cs}}$. The liquefied shear strength $S u(\mathrm{LIQ})$, is the shear strength mobilized at large deformation after liquefaction and also, the yield shear strength $S u$ (yield) is the peak undrained loading of a saturated, contractive soil. Several investigations have proposed procedures to estimate shear strength of liquefied soils [11] [21] [36]-[38] and yield strength [39] [40]. The yield and liquefied shear strength as defined:

$$
\begin{gathered}
S_{u}(\text { yield })=\frac{q_{u}(\text { yield })}{2} \\
S_{u}(L I Q)=\frac{q_{S S}}{2} \operatorname{COS} \phi^{\prime} s S
\end{gathered}
$$

where $\phi^{\prime}$ s is the steady-state friction angle.

The Liquefied strength ratio and yield strength ratio are defined as the liquefied shear strength and the yield shear strength, normalized by prefailure vertical stress, $S u(L I Q) / \sigma_{v 0}$, $S u$ (yield) $\sigma /{ }^{\prime}{ }_{v 0}$ respectively. Stark and Mesri (1992) [37] proposed a correlation between liquefied strength ratio and normalized penetration resistance:

$$
\frac{S_{u}(L I Q)}{\sigma_{V 0}^{\prime}}=0.0055\left(N_{1}\right)_{60-C S}
$$

The number of SPT bellows are achieved from relation of Skempton (1986) [41] and Kulhawy and Mayne (1990) [42] to account for the effect of grain size on the relative between $\left(N_{1}\right)_{60}$ and relative density observed by following relation:

$$
\frac{\left(N_{1}\right)_{60}}{D r^{2}}=60+25 \log D_{50}
$$

where $D_{50}$ is median grain diameter in millimeters. Figure 11 shows the boundaries for liquefied strength ratio proposed by Stark and Mesri (1992) [37] in Equation (7) and Davies and Campanella (1994) [43] and Olson and 


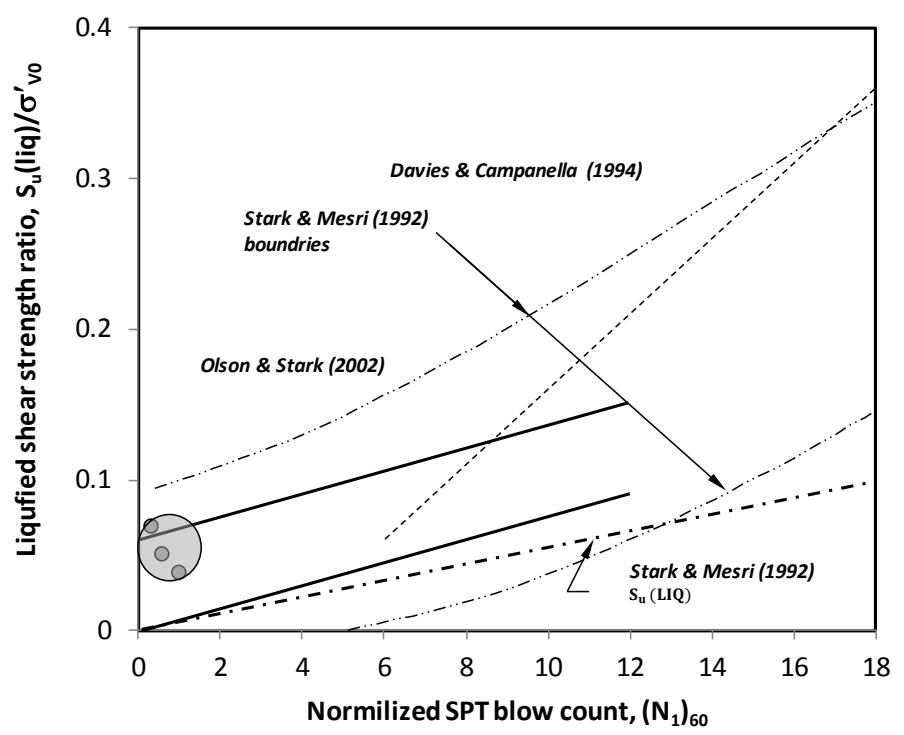

Figure 11. Comparison of liquefied strength ratio relationship based on normalized SPT blowcount for Babolsar sand.

Stark (2002) [7]. To compare liquefaction potential of Babolsar sand with that of other studies, as Olson \& Stark (2002) [7] noted, the relative density must be normalized to penetration resistance. Therefore, the data relevant to Babolsar sands which had undergone liquefaction is normalized by Equation (9) in terms of per SPT blows. By using the back-analyzed method and embedding the numbers in Figure 11, it could be seen that the liquefaction samples A1 to A3, which are in the shaded zone, located on Olson \& Stark (2002) [7] upper bounds.

Baziar and Dobry (1995) [44] and Olson and Stark (2002) [7] proposed the relationships between liquefied shear strength and prefailure vertical effective stress as shown Figure 12. Of course, Baziar and Dobry (1995) [44] further analyzed the case histories used by Seed and Harder (1990) [36] and Stark and Mesri (1992) [37] and developed these boundaries. The shaded zone is related to the liquefiable Babolsar sand specimens which are located at the bottom of the Baziar and Dobry (1995) [44], $\left(S u(L I Q)=0.04 \sigma_{v 0}^{\prime}\right)$, and Olson and Stark (2002) [7], $\left(S u(L I Q)=0.05 \sigma_{v 0}\right)$, boundaries. The bands presented by researchers in Figure 11 and Figure 12 shows a boundary for various case histories which have undergone liquefaction. All researchers attempt to reduce the limit of such bands to obtain comprehensive relations for various kinds of soil. By comparing the shaded zone which is related to the experimental results of Babolsar sand and other bands presented in these figures, it could be said that Babolsar sand behavior has a good correlation with other kinds of sands in the world. Also, it is possible to utilize relations presented by Olson and Stark (2002) [7] in engineering and theoretical practices on such special sands.

\section{Summary and Conclusions}

The current study investigates isotropically and anisotropically consolidated drained and undrained behaviour of Babolsar sand which is widely deposited in southern coast of Caspian Sea. Also, numerous strain-controlled triaxial tests were conducted on the reconstituted specimens of this sand. Based on the results, discussions and comparisons presented in the above sections the following conclusions are drown:

1) In the undrained triaxial test under monotonic loading, Babolsar sand can experience the whole possible behaviours of liquefiable soils i.e. flow failure, limited liquefaction, and dilation. Loose samples with the initial relative density of about $8.48 \%$ have flow failed even under relatively low levels of effective confining pressure (say $40 \mathrm{kP}$ ). Nevertheless, majority of the conducted triaxial tests have shown dilative behaviour.

2) Pore pressure parameter $\left(A_{f}\right)$ and excess pore water pressure ratio $\left(r_{u}\right)$ can reflect the susceptibility of sand for contractive or dilative types of failure loading. For example, for the loos samples A1 to A5, in which the pore water pressure increases during testing, $A_{f}$ and ru vales take a positive value. However, for the remaining samples with decreasing pore water pressure at the moment of failure, these indices takes a negative value.

3) The collapse line is the boundary between stable and unstable zone in undrained specimens. The angle of 


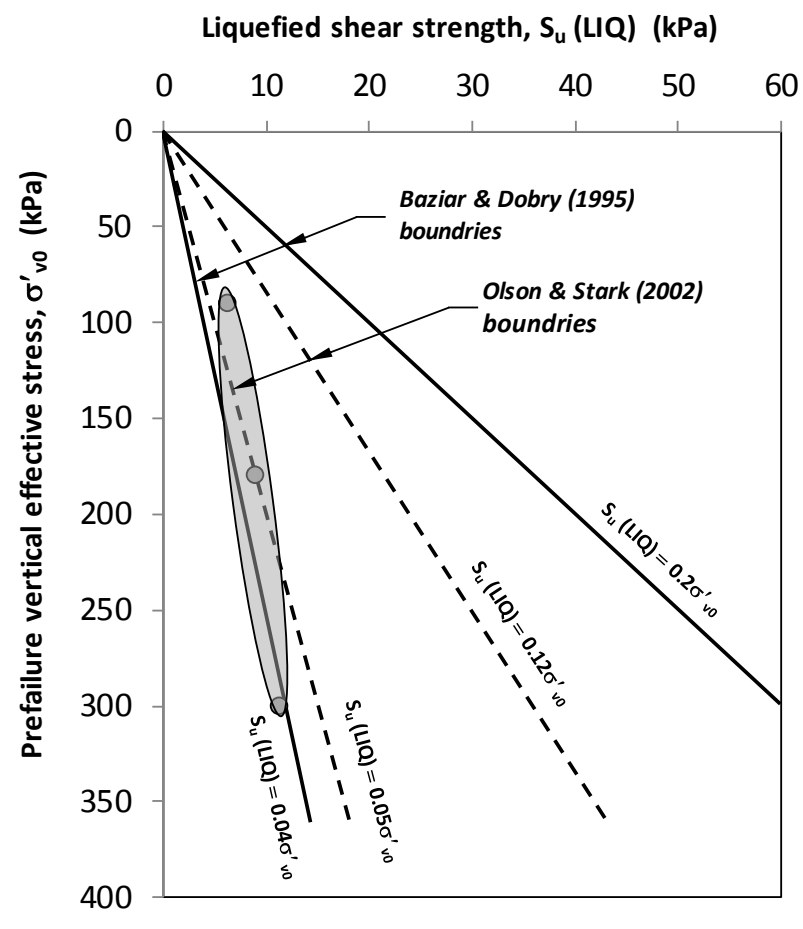

Figure 12. Comparison of liquefied shear strength relationship versus prefailure vertical effective stress for Babolsar sand.

this line for Babolsar sand is 47.14 degree, and the angle of the steady-state line for all triaxial test data is 54.14 degree. If the specimen locates over this line, it will be deformed.

4) Increase in relative density greatly reduces the amount of liquefaction potential. The state parameter rate, in the loose samples A1 to A5, ranges from 0.01 to 0.03 . While for the samples A6 to A10, this rate ranges between -0.02 to -0.05 , and for dense samples A11 to A15 ranges between -0.075 to -0.15 . This indicates the extreme severity of dilation of such sample in relation to the increased susceptibility of the relative density.

5) A comparison between the results of Babolsar sand and other results obtained by researchers on different types of sands in the Figures 9-12 indicates that there is a good correlation between behavior of Babolsar sand and that of different types of clean sands. Also, investigations on such boundaries show that the results of Babolsar sand locate over Olson and Stark (2002) [7] band. This boundary is more reasonable and complete than other presented ones (for the current study). Therefore, it is possible to utilize the relations presented by Olson and Stark (2002) [7] in engineering and theoretical practices on such special sands.

\section{References}

[1] Castro, G. (1969) Liquefaction of Sand. Ph.D. Thesis, Division of Engineering and Applied Physics, Harvard University, Cambridge.

[2] Casagrande, A. (1975) Liquefaction and Cyclic Deformation of Sands, a Critical Review. Proceedings of 5th Pan American Conference Soil Mechanic, Foundation Engineering, Buenos Aires, 80-133.

[3] Castro, G. and Poulos, S.J. (1977) Factors Affecting Liquefaction and Cyclic Mobility. Journal of Geotechnical Engineering, ASCE, 103, 501-516.

[4] Poulos, S.J. (1981) The Steady State of Deformation. Journal of Geotechnical Engineering, Div, Am, Society Civil, 107, 553-562.

[5] Been, K. and Jefferies, M.G. (1985) A State Parameter for Sands. Géotechnique, 35, 99-112. http://dx.doi.org/10.1680/geot.1985.35.2.99

[6] Jafarian, Y., Ghorbani, A. and Salamatpoor, S. (2012) Experimental Study on Shear Resistance of Babolsar Sand under Anisotropic Consolidation. 3rd International Conference on New Developments in Soil Mechanics and Geotechnical Engineering, Cyprus. 
[7] Olson, S.M. and Stark, T.D. (2002) Liquefied Strength Ratio from Liquefaction Flow Failure Case Histories. Canadian Geotechnical Journal, 39, 629-647. http://dx.doi.org/10.1139/t02-001

[8] Wadell, H.A. (1932) Volume, Shape and Roundness of Rock Particles. The Journal of Geology, 40, 443-451. http://dx.doi.org/10.1086/623964

[9] Lade, P.V. and Duncan, J.M. (1973) Cubical Triaxial Tests on Cohesionless Soil. Journal of Soil Mechanics and Foundations, Div, ASCE, 793-812.

[10] Sivathayalan, S. and Vaid, Y.P. (2002) Influence of Generalized Initial State and Principal Stress Rotation on the Undrained Response of Sands. Canadian Geotechnical Journal, 39, 63-76. http://dx.doi.org/10.1139/t01-078

[11] Poulos, S.J., Castro, G. and France, J.W. (1985) Liquefaction Evaluation Procedure. Journal of Geotechnical Engineering, 111, 772-792. http://dx.doi.org/10.1061/(ASCE)0733-9410(1985)111:6(772)

[12] Fear, C.E. and Robertson, P.K. (1995) Reconsideration of Initiation of Liquefaction in Sandy Soils. Journal of Geotechnical Engineering, 121, 249-261. http://dx.doi.org/10.1061/(ASCE)0733-9410(1995)121:3(249)

[13] Olson, S.M. and Stark, T.D. (2003) Use of Laboratory Data to Confirm Yield and Liquefied Strength Ratio Concepts. Canadian Geotechnical Journal, 40, 1164-1184. http://dx.doi.org/10.1139/t03-058

[14] Hanzawa, H., Itoh, Y. and Suzuki, K. (1979) Shear Characteristics of a Quick Sand in the Persian Gulf. Soils and Foundations, 19, 1-15. http://dx.doi.org/10.3208/sandf1972.19.4 1

[15] Sladen, J.A., D’Hollander, R.D. and Krahn, J. (1985) The Liquefaction of Sands, a Collapse Approach. Canadian Geotechnical Journal, 22, 564-578. http://dx.doi.org/10.1139/t85-076

[16] Vaid, Y.P. and Chern, J.C.L. (1983) Effect of Static Shear on Resistance to Liquefaction. Soils and Foundations, 23, 47-60. http://dx.doi.org/10.3208/sandf1972.23.47

[17] Kramer, S.L. and Seed, H.B. (1988) Initiation of Soil Liquefaction under Static Loading Conditions. Journal of Geotechnical Engineering, 114, 412-430. http://dx.doi.org/10.1061/(ASCE)0733-9410(1988)114:4(412)

[18] Vasquez-Herrera, A. and Dobry, R. (1989) Re-Evaluation of the Lower San Fernando Dam. Report 3. The Behavior of Undrained Contractive Sand and Its Effect on Seismic Liquefaction Flow Failures of Earth Structures. U.S. Army Corps of Engineering, Contract Report GL-89-2. US Army Corps of Engineering Waterways Experiment Station, Vicksburg.

[19] Lade, P.V. (1992) Static Instability and Liquation of Loose Fine Sandy Slopes. Journal of Geotechnical Engineering, 118, 51-71. http://dx.doi.org/10.1061/(ASCE)0733-9410(1992)118:1(51)

[20] Lade, P.V. (1993) Initiation of Static Instability in the Submarine Nerlerk Berm. Canadian Geotechnical Journal, 30, 895-904. http://dx.doi.org/10.1139/t93-088

[21] Ishihara, K. (1993) Liquefaction and Flow Failure during Earthquake. Géotechnique, 43, 351-415. http://dx.doi.org/10.1680/geot.1993.43.3.351

[22] Konrad, J.M. (1993) Undrained Response of Loosely Compacted Sands during Monotonic and Cyclic Compression Tests. Géotechnique, 43, 69-89. http://dx.doi.org/10.1680/geot.1993.43.1.69

[23] Sasitharan, S., Robertson, P.K., Sego, D.C. and Morgenstern, N.R. (1993) Collapse Behavior of Sand. Canadian Geotechnical Journal, 30, 569-577. http://dx.doi.org/10.1139/t93-049

[24] Sasitharan, S., Robertson, P.K., Sego, D.C. and Morgenstern, N.R. (1994) State-Boundary Surface for Very Loose Sand and Its Practical Implications. Canadian Geotechnical Journal, 31, 321-334. http://dx.doi.org/10.1139/t94-040

[25] Konrad, J.M. (1990) Minimum Undrained Strength of Two Sands. Journal of Geotechnical Engineering, 116, $932-947$. http://dx.doi.org/10.1061/(ASCE)0733-9410(1990)116:6(932)

[26] Canou, J., Bahda, F., Saitta, A. and Dupla, J.C. (1994) Initiation of Sand Liquefaction under Monotonic and Cyclic Loading. In: Balkema, A.A., Ed., Proceedings of the 13th International Conference on Soil Mechanics and Foundation Engineering, Vol. 3, Rotterdam, 1297-1300.

[27] Riemer, M.F., Seed, R.B., Nicholson, P.G. and Jong, H.L. (1990) Steady State Testing of Loose Sands: Limiting Minimum Density. Journal of Geotechnical Engineering, 116, 332-337. http://dx.doi.org/10.1061/(ASCE)0733-9410(1990)116:2(332)

[28] Riemer, M.F. and Seed, R.B. (1992) Observed Effects of Testing Conditions on the Residual Strength of Loose, Saturated Sands at Large Strains. In: Hamada, M. and O’Rourke, T.D., Eds., Proceedings of the 4th Japan-US Workshop on Earthquake Resistant Design of Lifeline Facilities and Countermeasures for Soil Liquefaction, Earthquake Engineering Research Center, Technical Report NCEER-92-0019, Vol. 1, National Center for Earthquake Engineering Research (NCEER), Buffalo, 223-237.

[29] Riemer, M.F. and Seed, R.B. (1997) Factors Affecting Apparent Position of Steady State Line. Journal of Geotechnical and Geoenvironmental Engineering, 12, 281-288. http://dx.doi.org/10.1061/(ASCE)1090-0241(1997)123:3(281) 
[30] Chu, J. (1995) An Experimental Examination of Critical State and Other Similar Concepts for Granular Soils. Canadian Geotechnical Journal, 32, 1065-1075. http://dx.doi.org/10.1139/t95-104

[31] Konrad, J.M. and Pouliot, N. (1997) Ultimate State Reconstituted and Intact Samples of Deltaic Sand. Canadian Geotechnical Journal, 34, 737-748. http://dx.doi.org/10.1139/T97-039

[32] Konrad, J.M. (1998) Sand State from Cone Penetration Tests: A Framework Considering Grain Crushing Stress. Géotechnique, 48, 201-215. http://dx.doi.org/10.1680/geot.1998.48.2.201

[33] Kolbuszewski, J.J. (1948) An Experimental Study of the Maximum and Minimum Porosities of Sand. Proceedings of the 4th International Conference on Soil Mechanics and Foundation Engineering, Rotterdam, 21-30 June 1948, 158-165.

[34] Bolton, M.D. (1986) The Strength and Dilatancy of Sands. Géotechnique, 36, 65-78. http://dx.doi.org/10.1680/geot.1986.36.1.65

[35] Seed, H.B. (1987) Design Problems in Soil Liquefaction. Journal of Geotechnical Engineering, 113, 827-845. http://dx.doi.org/10.1061/(ASCE)0733-9410(1987)113:8(827)

[36] Seed, R.B. and Harder, L.F. (1990) SPT-Based Analysis of Cyclic Pore Pressure Generation and Undrained Residual Strength. In: Duncan, J.M., Ed., Proceedings of the H.B. Seed Memorial Symposium, Vol. 2, BiTech Publishers, Richmond, 351-376.

[37] Stark, T.D. and Mesri, G. (1992) Undrained Shear Strength of Liquefied Sands for Stability Analysis. Journal of Geotechnical Engineering, 118, 1727-1747. http://dx.doi.org/10.1061/(ASCE)0733-9410(1992)118:11(1727)

[38] Konrad, J.M. and Watts, B.D. (1995) Undrained Shear Strength for Liquefaction Flow Failure Analysis. Canadian Geotechnical Journal, 32, 783-794. http://dx.doi.org/10.1139/t95-076

[39] Terzaghi, K., Peck, R.B. and Mesri, G. (1996) Soil Mechanics in Engineering Practice. 3rd Edition, John Wiley and Sons, Inc., New York.

[40] Olson, S.M. and Stark, T.D. (2003) Yield Strength Ratio and Liquefaction Analysis of Slopes and Embankments. Journal of Geotechnical and Geoenvironmental Engineering, 129, 727-737. http://dx.doi.org/10.1061/(ASCE)1090-0241(2003)129:8(727)

[41] Skempton, A.W. (1986) Standard Penetration Test Procedures and the Effects in Sand of Overburden Pressure, Relative Density, Particle Size, Ageing and Overconsolidation. Géotechnique, 36, 425-447. http://dx.doi.org/10.1680/geot.1986.36.3.425

[42] Kulhawy, F.H. and Mayne, P.W. (1990) Manual on Estimating Soil Properties for Foundation Design. Electric Power Research Institute EL-6800, Project 1493-6, Electric Power Research Institute, Palo Alto, Calif.

[43] Davies, M.P. and Campanella, R.G. (1994) Selecting Design Values of Undrained Strength for Cohesionless Soils. In: Proceeding of the 47th Canadian Geotechnical Conference, Vol. 1, BiTech Publishers, Richmond, 176-186.

[44] Baziar, M.H. and Dobry, R. (1995) Residual Strength and Large Deformation Potential of Loose Silty Sands. Journal of Geotechnical Engineering, 121, 896-906. http://dx.doi.org/10.1061/(ASCE)0733-9410(1995)121:12(896) 
Scientific Research Publishing (SCIRP) is one of the largest Open Access journal publishers. It is currently publishing more than 200 open access, online, peer-reviewed journals covering a wide range of academic disciplines. SCIRP serves the worldwide academic communities and contributes to the progress and application of science with its publication.

Other selected journals from SCIRP are listed as below. Submit your manuscript to us via either submit@scirp.org or Online Submission Portal.
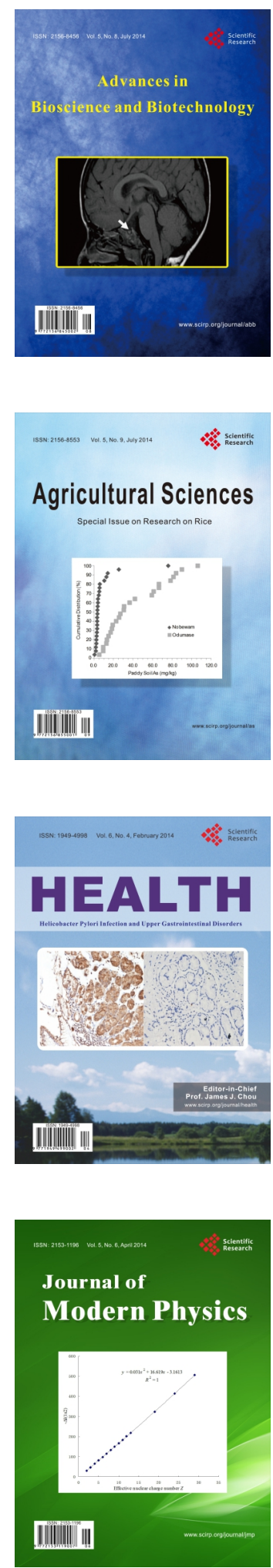
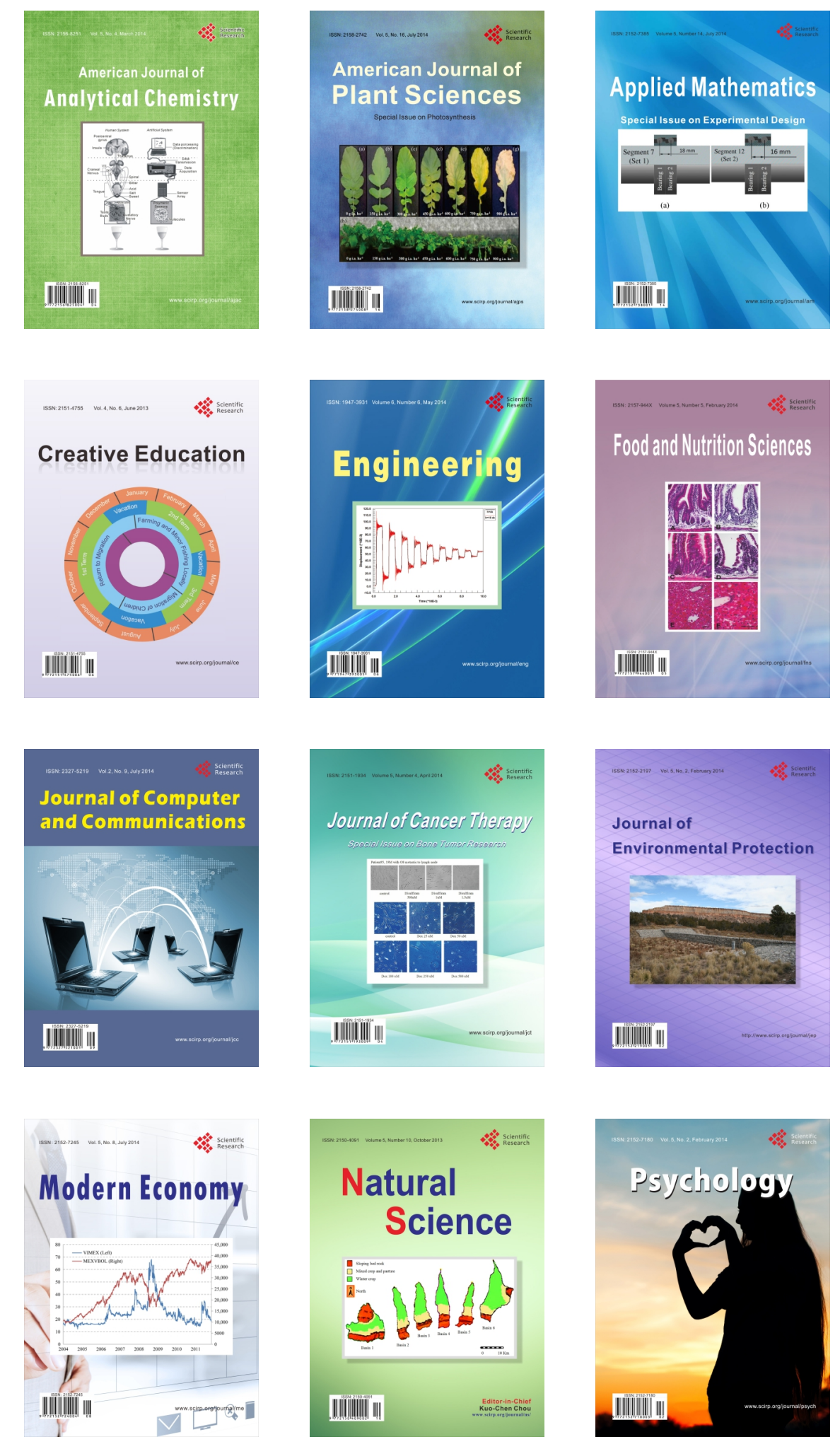